\title{
ANALISIS CLAIM NELAYAN TIONGKOK ATAS TRADITIONAL FISHING GROUND DI PERAIRAN NATUNA
}

\section{Syafril Ernandi, Muridah Isnawati, Adhy Riadhy Arafah}

Fakultas Hukum, Universitas Muhammadiyah Surabaya

J1. Raya Sutorejo No.59, Dukuh Sutorejo, Mulyorejo, Kota Surabaya, Jawa Timur 60113, Telp/Fax: (031) 3811966, e-mail: aisitheru1994@gmail.com

\begin{abstract}
Abstrak
Sebagai Negara kepulauan Indonesia mempunyai kedaulatan atas wilayah laut di bawahnya serta ruang udara di atasnya, hal ini tetuang dalam Undang-Undang Dasar (UUD) 1945 pasal 33 ayat 3 . Faktanya Potensi sumber daya alam di perairan natuna ini memicu konflik dengan negara Tiongkok. Metode penelitian yuridis normatif dengan pendekatan statute approach. Hasil peneltian pertama bahwa Berdasarkan ketentuan pasal 56 United Nations Convention on the Law of the sea (Konvensi Perserikatan Bangsa-Bangsa Tentang Hukum Laut 1982) serta pasal 4 ayat 1 Undang-Undang nomor 5 Tahun 1983 Tentang Zona Ekonomi Eksklusif Indonesia maka Kepulauan Natuna merupakan negara pantai yang masuk ke dalam wilayah zona ekonomi eksklusif Indonesia yang berjarak 200 mil laut. Demikian Indonesia memiliki hak berdaulat untuk melakukan eksplorasi dan eksploitasi, konservasi serta pengelolaan sumber kekayaan alam, baik hayati maupun non-hayati, dari perairan diatas, dasar laut dan tanah dibawahnya, khususnya kegiatan penagkapan ikan di Kepulauan Natuna, Hasil penelitian kedua adalah Penangkapan ikan (illegal fishing) yang dilakukan oleh Tiongkok dengan disertai klaim Traditional Fishing Ground di Kepulauan Natuna ini tidak dikenal dalam UNCLOS 1982 melainkan hanya mengenal Traditional Fishing Right yang tertuang dalam Bab IV pasal 51 ayat (1) Konvensi Hukum Laut 1982. Demikian klaim Traditional Fishing Ground oleh Tiongkok tidak mempunyai dasar hukum internasional atau bertentangan dengan UNCLOS 1982.
\end{abstract}

Kata Kunci : Hak Berdaulat, ZEE, Traditional Fishing Ground

\section{A. Pendahuluan}

Sebagai Negara kepulauan Indonesia mempunyai kedaulatan atas perairan kepulauan, perairan pedalaman, dasar laut dan dasar tanah di bawahnya serta ruang udara di atasnya, hal ini tetuang dalam Undang-Undang Dasar (UUD) 1945 pasal 33 ayat 3 yang berbunyi "Bumi, air, dan kekayaan alam yang terkandung didalamnya dikuasai oleh Negara dan dipergunakan untuk sebesar-besarnya kemakmuran rakyat". Tidak bisa disangkal lagi bahwa menjaga dan melindungi sepenuhnya setiap jengkal republik ini adalah amanat konstitusi untuk menjaga kedaulatan NKRI. Dalam pembukaan Undang-Undang Dasar (UUD) 1945 secara tegas memaktubkan bahwa melindungi segenap tumpah darah Indonesia ialah 
salah satu tujuan mengapa negeri ini berdiri dan berdaulat karena itu sikap tegas terhadap siapa pun dan dari pihak mana pun yang mengganggu serta mengancam kedaulatan wilayah Indonesia merupakan keniscayaan.

Laut natuna yang secara administrasi masuk dalam kepulauan riau dengan luas wilayah $2.009,04 \mathrm{~km}^{2} .{ }^{1}$ Kabupaten ini kaya akan sumber daya alam dari sektor penghasil minyak dan gas, di perkirakan cadangan minyak bumi sekitar 400.386.470 barel dan gas bumi 112.356.680.000. Potensi perikanan tangkap di perairan natuna provinsi kepulaun riau ini merupakan penghasil terbesar dengan tingkat pemanfaatan baru mencapai $4-6 \%$ dari total potensi kabupaten natuna sebesar 504.212,85 ton/tahun ${ }^{2} \quad(58,59 \%$ dari total potensi Provinsi Kepulauan Riau).

potensi sumber daya alam di perairan natuna ini memicu konflik dengan negara Tiongkok. Insiden ini terjadi pada maret 2016, kapal KM Kway Fey 10078, dan mei 2016, kapal Gui Bei Yu 27088, menangkap ikan secara illegal di perairan

\footnotetext{
${ }^{1}$ Wikipedia, (2016), tersedia pada https://id.wikipedia.org/wiki/Kabupaten_Natuna [akses 18 Maret 2017].

${ }^{2}$ Bappeda Kepulauan Riau, (2016), Potensi daerah di sektor perikanan, tersedia pada http://bappeda.kepriprov.go.id/index.php/data-daninformasi/2013-02-04-08-49-43/91-potensidaerah/180-sektor-perikanan [Akses 18 Maret 2016]
}

natuna. Dalam proses penagkapan kapal KM Kway Fey 10078 oleh KP Hiu 11², terjadi perlawanan oleh Tiongkok dengan sengaja kapal coastguard menabrak dan menggiring KM Kway Fey keluar jauh dari perairan natuna. Fenomena ini menunjukan bahwa Tiongkok sudah mengintervensi penegakan hukum IUU Fishing di Indonesia. Konflik ini semakin panas ketika pemerintah Tiongkok mengklaim bahwa wilayah tersebut merupakan kawasan Traditional Fishing Ground $^{4}$ dengan memasukan perairan natuna ke dalam peta teritorialnya dengan istilah nine-dashed line.

Dalam hal ini nelayan RRT melakukan pelanggaran hak berdaulat, yurisdiksi di ZEE serta di landasan kontinen kepulauan Indonesia sesuai dengan United Nations Convention on the Law of the Sea (Konvensi Perserikatan Bangsa-Bangsa Tentang Hukum Laut 1982).

Maka dalam tulisan ini perlu ada analisis terkait klaim nelayan RRT atas Traditional Fishing Ground di periran natuna, hal ini di upayakan agar

\footnotetext{
${ }^{3}$ Rmol, (2016), Susi: tidak benar itu traditional fisging ground China, tersedia pada http://m.rmol.co/read/2016/03/21/240299/MenteriSusi:-Tidak-Benar-Itu-Traditional-Fishing-GroundChina- [Akses 28 Maret 2017]

4 Metro Xinmen, (2016) pemerintah RRT klaim Traditional Fishing Ground atas perairan natuna,
} 
memberikan penjelasan terhadap klaim sepihak oleh pemerintah RRT yang tidak mempunyai dasar hukum internasional dan perjanjian internasional. Serta sah dan tidaknya terkait illegal fishing di perairan natuna.

\section{B. Metode Penelitian}

Metode penelitian hukum yang digunakan dalam penulisan yuridis normatif, sedangkan pendekatan yang digunakan adalah pendekatan Statute approach, atau suatu pendekatan yang beranjak dari Perundang-undangan yang beraku dalam konvensi PBB dan di Indonesia yang memecahkan isu hukum yang diajukan, serta didasarkan pada peraturan perundang-undangan sebagai sentral kajian dan regulasi yang bersangkutan dengan isu hukum yang ditangani baik secara vertikal maupun horizontal, ${ }^{5}$ dari dasar hukum yuridis menjadi sasaran peneliti untuk menyusun argumentasi hukum serta pendapat hukum dalam memecahkan isu hukum yang sedang di teliti. ${ }^{6}$

\section{Pembahasan}

\footnotetext{
${ }^{5}$ Asri Wjiayanti, (2005), Strategi Penulisan Hukum Normatif, Bandung: Lubuk Agung, hlm. 71.

6 Romy Hanitijo Soemitro. (1994), Metodelogi Penelitian Hukum dan Jurimetri. Cetakan Kelima. Jakarta: Ghalia Indonesia, hlm. 10Op Cit, hal. 74
}

Pengertian Kedaulatan dan Hak Berdaulat

Zonasi Laut Berdasarkan UNCLOS 1982

Berdasarkan ketentuan United Nations Convention on the Law of the Sea (Konvensi Perserikatan Bangsa-Bangsa Tentang Hukum Laut 1982), zona laut dapat dibedakan berdasarkan dua prinsip hukum internasional yang berbeda yakni kedaulatan (sovereignty) dan hak berdaulat (sovereign rights) suatu negara di wilayah laut. Adapun pengertian kedaulatan menurut pasal 2 UNCLOS 1982 bahwa negara pantai mempunyai kedaulatan penuh atas perairan pedalaman yang meliputi ruang udara diatasnya, dasar laut dan tanah dibawahnya yang terletak di atas laut teritorial. ${ }^{7}$ Dalam hal ini negara pantai memiliki kekuasaan tertinggi di wilayah laut yang diatur dalam hukum nasionalnya. ${ }^{8}$

Di samping itu, di luar laut teritorial, sebuah negara pantai tidak memiliki kedaulatan penuh (sovereignty) tetapi memiliki hak berdaulat (sovereign rights) pengertian ini termuat dalam dalam ketentuan pasal 56 UNCLOS 1982yakni hak untuk mengelola dan

\footnotetext{
7 Mohammad Sodik, Didik, (2011), Hukum Laut Internasional Dan Pengaturannya Di Indonesia, Bandung : Refika Aditama, hlm.4

${ }^{8}$ Mochtar Kusumaatmadja, (1986), Hukum Laut Internasional, Bandung: Penerbit Binacipta, 1986, hlm 3 .
} 
memanfaatkan untuk keperluan eksplorasi dan eksploitasi, konservasi dan pengelolaan sumber daya alam baik hayati dan non-hayati dari perairan di atas dasar laut dan dari dasar laut dan tanah dibawahnya dan berkenan dengan kegiatan lain untuk keperluan eksplorasi dan eksploitasi zona ekonomi tersebut, seperti produksi energi dari air, arus dan angin. ${ }^{9}$

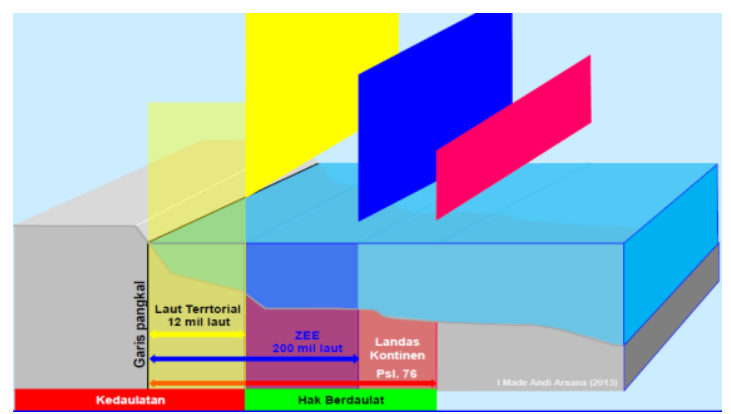

Gambar 1: Kawasan kedaulatan dan hak berdaulat. Sumber: IMade Arsana (2013)

Kawasan tempat berlakunya hak berdaulat ini dikenal dengan yurisdiksi, bukan wilayah atau territory. Sebagai contoh di Zona Ekonomi Eksklusif (ZEE), Indonesia tidak punya kedaulatan penuh tetapi berhak untuk mengelola kekayaan alamnya dan negara lain tidak berhak memanfaatkan kekayaan alam itu tanpa izin dari Indonesia.

\footnotetext{
${ }^{9}$ United Nations Convention on the Law of the Sea (Konvensi Perserikatan Bangsa-Bangsa Tentang Hukum Laut 1982) Pasal 56 tentang hak-hak, yurisdiksi dan kewajiban negara pantai dalam zona ekonomi eksklusif
}

Ketentuan-Ketentuan Umum Mengenai Zona Ekonomi Eksklusif Berdasarkan Undang-Undang No 5 Tahun 1983 Tentang Zona Ekonomi Eksklusif Indonesia

Sebagai negara peserta konvensi hukum laut 1982, Indonesia telah mengeluarkan Undang-Undang No 5 Tahun 1983 Tentang Zona Ekonomi Eksklusif Indonesia. Secara garis besar, pengaturan ini termuat tentang hak-hak dan kewajiban Indonesia dan kebebasankebebasan negara lain di Zona Ekonomi Eksklusif, konservasi dan pengelolaan sumber daya ikan di laut. Dalam pasal 2 UU ZEEI terdapat pengertian bahwa jalur diluar dan perbatasan dengan wilayah laut Indonesia sebagaimana yang ditetapkan berdasarkan undang-undang yang berlaku tentang perairan Indonesia yang meliputi dasar laut, tanah dibawanya dan perairan diatasnya dengan batas terluar 200 mil laut dengan di ukur dari garis pangkal laut wilayah Indonesia. Dalam hak berdaulat, yang terdapat pasal 56 UNCLOS 1982 telah dirumuskan dalam pasal 4 ayat 1UU No 5 Tahun 1983 Tentang Zona Ekonomi Eksklusif Indonesia. ${ }^{10}$

\footnotetext{
${ }^{10}$ Undang-Undang No 5 Tahun 1983 Tentang Zona Ekonomi Eksklusif Indonesia pasal 4 ayat 1 tentang hak berdaulat Indonesia atas ZEE
} 
Bahwa Indonesia mempunyai hak berdaulat untuk melaksanakan eksplorasi dan eksploitasi, konservasi dan pengelolaan sumber daya alam yang berada di dasar laut, tanah di bawahnya dan perairan diatasnya. Dalam pasal 1 disebutkan Indonesia mempunyai yurisdiksi yang berkaitan dengan:

1. Pembuatan dan Penggunaan pulau buatan, isntalasi-instalasi dan bangunan-bangunan lainnya.

2. Penelitian ilmiah mengenai kelautan, dan pelestarian lingkungan laut.

3. Hak-hak dan kewajiban lainnya berdasarkan UNCLOS 1982

Selanjutnya dalam pasal $3 \mathrm{UU}$ ZEEI mengakui kebebasan berlayar dan penerbangan internasional dan pemasangan kabel dan pipa dibawah laut sesuai dengan prinsip hukum internasional yang berlaku. Kemudian, dalam hal kegiatan eksplorasi dan eksploitasi sumber daya ikan harus melakukan perizinan kepada pemerintah Indonesia atau berdasarkan persetujuan internasional dengan Pemerintah Republik Indonesia. Disamping itu, apabila Indonesia surplus tangkap ikan, maka badan hukum atau pemerintah asing diperbolehkan untuk ikut turut serta dalam memanfaatkannya sumber daya ikan yang ada, dengan catatan harus dapat perizinan dalam melakukan eksplorasi dan eksploitasi di ZEE Indonesia.

Dalam hal penegakan hukum di laut, pasal 13 UU ZEEI bahwa tindakan sesuai dengan untuk pelaksanaan hak berdaulat, yurisdiksi dan kewajibankewajiban lain, maka aparatur penegak hukum berwenang mengambil tindakantindakan penegakan hukum, hal ini sesuai dengan Undang-Undang No 8 Tahun 1981 tentang Kitab UU Acara Pidana. Ada pun pengecualian terhadap tindakan-tindakan penegakan hukum diantaranya, penagkapan kapal atau orang yang di duga melakukan pelanggaran di ZEEI meliputi, pemberhentian kapal dan diserahkannya kapal dan orang tersebut untuk diproses lebih lanjut. ${ }^{11}$

Dalam hal pembebasan kapal dan nahkodanya, pasal 15 ayat 1 UU ZEEI menyatakan bahwa untuk membebaskan dan orang yang ditangkap karena melanggar UU tersebut bisa dilakukan sebelum ada putusan dari pengadilan negeri. Kemudian dalam ayat 2 menyatakan bahwa permohonan pembebasan dapat di kabulkan kecuali

\footnotetext{
11 Ria Siombo Marhaeni. (2010). Hukum Poerikanan Nasional dan Internasional, Jakarta : Gramedia Pustaka Utama, hlm.93.
} 
sudah menyerahkan uang jaminan yang sudah di tentukan oleh pengadilan negeri.

Implementasi Ketentuan-Ketentuan Umum Mengenai Zona Ekonomi Eksklusif Berdasarkan UNCLOS 1982

Ketentuan umum zona ekonomi eksklusif diatur dalam pasal 55 sampai dengan pasal 75 UNCLOS 1982. Dengan memperhatikan konvensi tersebut maka suatu negara dapat mengklaim wilayah zona ekonomi eksklusifnya sampai 200 mil, berkaitan dengan adanya UNCOLS 1982 Indonesia telah meratifikasi United Nations Convention on the Law of the Sea(Konvensi Perserikatan Bangsa-Bangsa Tentang Hukum Laut 1982) kedalam Undang-Undang No. 17 Tahun 1985. Dalam implementasinya UNCLOS 1982 berjalan dengan seirama Undang-Undang No. 5 Tahun 1983 tentang Zona Ekonomi Eksklusf Indonesia.

Ketentuan-ketentuan umum tentang zona ekonomi eksklusif diatur dalam $\mathrm{BAB}$ V UNCLOS 1982 mulai pasal 55 sampai dengan pasal 75, pasal-pasal tersebut mengatur diantaranya: ${ }^{12}$

\footnotetext{
${ }^{12}$ United Nations Convention on the Law of the Sea (Konvensi Perserikatan Bangsa-Bangsa Tentang Hukum Laut 1982) BAB V Zona Ekonomi Eksklusif Pasal 55-75.
}

Pasal 55 : tentang rezim hukum khusus zona ekonomi eksklusif.

Pasal 56 :tentang hak-hak yurisdiksi dan kewajiban negar pantai dalam zona ekonomi eksklusif.

Pasal 57 : tentang lebar zona ekonomi eksklusif.

Pasal 58 : tentang hak-hak dan kewajiban negara lain di zona ekonomi eksklusif.

Pasal 59 : tentang dasar untuk penyelesaian sengketa mengenai pemberian hak-hak dan yurisdiksi di zona ekonomi eksklusif.

Pasal 60 : tentang pulau buatan, instalasi dan bangunan-bangunan di zona ekonomi eksklusif.

Pasal 61 : tentang konservasi sumber kekayaan hayati.

Pasal 62 : tentang pemanfaatan sumber kekayaan hayati.

Pasal 63 : tentang persediaan jenis ikan yang terdapat di zona ekonomi eksklusif dua negara pantai atau lebih atau keduaduanya di dalam zona ekonomi eksklusif tersebut dan di dalam suatu daerah di luar serta berdekatan dengannya. 
Pasal 64 : tentang jenis ikan yang berimigrasi jauh (highly migratory species).

Pasal 65 : tentang mamalia laut.

Pasal 66 : tentang persediaan jenis ikan anadrom.

Pasal 67 : tentang persediaan jenis ikan catadrom.

Pasal 68 : tentang jenis sedenter.

Pasal 69 : tentang hak-hak negara tak berpantai.

Pasal 70 : tentang hak negara yang secara geografis tak beruntung.

Pasal 71 : tentang tidak berlakunya pasal 69 dan 70.

Pasal 72 : tentang pembatasan pengalihan hak.

Pasal 73 : tentang penegakan peraturan perundang-undangan negara pantai.

Pasal 74 : tentang penetapan batas zona ekonomi eksklusif antara negara yang pantainya berhadapan atau berdampingan.

Pasal 75 : tentang peta dan daftar koordinat geografis.
Sedangkan dalam hukum nasional ketentuan ZEE diatur dalam UndangUndang No. 5 Tahun 1983 tentang Zona Ekonomi Eksklusf Indonesia, ketentuan ini terdiri dari BAB I sampai dengan BAB IX dan pasal 1 sampai pasal 21. Pasal-pasal tersebut diantaranya mengatur tentang: ${ }^{13}$

Bab I : tentang ketentuan umum, terdiri dari pasal 1.

Bab II : tentang Zona Ekonomi Eksklusif Indonesia, terdiri dari pasal 2 dan pasa 3

Bab III : tentang Hak Berdaulat dan HakHak lain, Yurisdiksi dan KewajibanKewajiban, terdiri dari pasal 4.

Bab IV : tentang Kegiatan di Zona Ekonomi Eksklusif Indonesia, terdiri dari pasal 5, pasal 6, pasal 7 dan pasal 8.

Bab V : tentang Ganti Rugi, terdiri dari pasal 9, pasal 10, pasal 11 dan pasal 12 .

Bab VI : tentang Penegakan Hukum, terdiri dari pasal 13, pasal 14, pasal 15 .

Bab VII : tentang Ketentuan Pidana, terdiri dari pasal 16, pasal 17, pasal 18.

Bab VII : tentang Ketentuan Peralihan, terdiri dari pasal 19.

\footnotetext{
${ }^{13}$ Undang-Undang Republik Indonesia No. 5 Tahun 1983 Tentang Zona Ekonomi Eksklusif Indonesia, Bab I-IX, pasal 1-21.
} 
Bab IX : tentang Ketentuan Penutup, terdiri dari pasal 20, pasal 21, pasal 18 .

Analisis Mengenai Traditional Fishing

Ground Berdasarkan Mekanisme

UNCLOS 1982

Kepulauan Natuna merupakan kawasan zona ekonomi eksklusif yang berjarak 200 mil, sehingga Indonesia sebagai negara pantai mempunyai hak berdaulat untuk melakukan eksplorasi dan eksploitasi, konservasi dan pengelolaan sumber daya alam, termasuk ikan.

Kasus penagkapan ikan (illegal fishing) yang dilakukan oleh Tiongkok tercatat sudah tiga kali di kejar dan di tangkap karena tidak memiliki surat izin resmi dari pemerintah Indonesia. Kasus terakhir, penangkapan terhadap kapal bendera Tiongkok Han Tan Cou 19038 yang disertai kawalan kapal penjaga pantai (Coast Guard). ${ }^{14}$

Dalam kasus tersebut Tiongkok memprotes bahwa wilayah tersebut merupakan zona perairan perikanan tradisional (Traditional Fishing Ground).Namun klaim tersebut adalah hal yang tidak benar. Pasalnya UNCLOS

14 Nusantara News, (2016), Pakar: tidak ada traditional fishing ground China, tersedia pada http://nusantaranews.co/pakar-di-dalam-zee-tidakada-traditional-fishing-ground-china, [Akses 21 Maret 2017]
1982 tidak mengenal istilah Traditional Fishing Ground melainkan mengenal Traditional Fishing Right yang tertuang dalam Bab IV pasal 51 ayat (1) UNCLOS 1982 yang berbunyi:

"Tanpa mengurangi arti ketentuan pasal 49, Negara kepulauan harus menghormati perjanjian yang ada dengan Negara lain dan harus mengakui hak perikanan tradisional dan kegiatan lain yang sah Negara tetangga yang langsung berdampingan dalam daerah tertentu yang berada dalam perairan kepulauan. Syarat dan ketentuan bagi pelaksanaan hak dan kegiatan demikian termasuk sifatnya, ruang lingkup dan daerah dimana hak akan kegiatan demikian, berlaku, atas permintaan salah satu Negara yang bersangkutan harus diatur dengan perjanjian bilateral antara mereka. Hak demikian tidak boleh dialihkan atau dibagi dengan Negara ketiga atau warga negaranya". 15

Berdasarkan ketentuan diatas sangat jelas bahwa untuk mendapatkan hak tradisional perikanan Tiongkok tidak bisa di dapatkan secara langsung.Namun hak tersebut dapat diperoleh Tiongkok dengan

\footnotetext{
${ }^{15}$ United Nations Convention on the Law of the Sea (Konvensi Perserikatan Bangsa-Bangsa Tentang Hukum Laut 1982) Pasal 51 ayat (1) tentang hak perikanan tradisional (Traditional Fishing Rihgt)
} 
mengikuti prosedur yang sudah diatur dalam Konvensi Hukum Laut 1982 dan melakukan suatu perjanjian bilateral dengan pemerintah Indonesia.

Sejarah mencatat Tiongkok tidak pernah melakukan perjanjian bilateral dengan Indonesia dalam hal penagkapan ikan tradisional. Hingga saat ini Indonesia hanya mempunyai perjanjian bilateral Traditional Fishing Rightdengan Malaysia. Demikian klaim Traditional Fishing Ground oleh Tiongkok tidak mempunyai dasar hukum internasional dan sangat bertentangan dengan UNCLOS 1982 dimana Tiongkok merupakan salah satu anggota dalam konvensi tersebut.

\section{Kesimpulan}

Berdasarkan ketentuan pasal 56 United Nations Convention on the Law of the sea (Konvensi Perserikatan BangsaBangsa Tentang Hukum Laut 1982)serta pasal 4 ayat 1 Undang-Undang nomor 5 Tahun 1983 Tentang Zona Ekonomi Eksklusif Indonesia maka Kepulauan Natuna merupakan negara pantai yang masuk ke dalam wilayah Zona Ekonomi Eksklusif Indonesia yang berjarak 200 mil laut. Demikian Indonesiamemiliki hak berdaulat untuk melakukan eksplorasi dan eksploitasi, konservasi serta pengelolaan sumber kekayaan alam, baik hayati maupun non-hayati,dari perairan diatas, dasar laut dan tanah dibawahnya,khususnya kegiatan penagkapan ikan di Kepulauan Natuna.

Penangkapan ikan (illegal fishing) yang dilakukan oleh Tiongkok dengan disertai klaimTraditional Fishing Ground di Kepulauan Natuna ini tidak dikenal dalam UNCLOS 1982melainkan hanya mengenal Traditional Fishing Right yang tertuangdalam Bab IV pasal 51 ayat (1) Konvensi Hukum Laut 1982. Demikianklaim Traditional Fishing Ground oleh Tiongkok tidak mempunyai dasar hukum internasional atau bertentangan dengan UNCLOS 1982.

\section{E. Daftar Pustaka}

Buku

Asri Wjiayanti. 2005. Strategi Penulisan Hukum Normatif, Bandung : Lubuk Agung

Hanitijo Soemitro, Romy. 1994. Metodelogi Penelitian Hukum dan Jurimetri. Jakarta : Ghalia Indonesia

Kusumaatmadja, Mochtar. Hukum Laut Internasional, Bandung : Bina Cipta 
Sunyowati Dina, Narwati Enny. 2013. Buku Ajar Hukum Laut, Surabaya : Airlangga University Press

Ria Siombo Marhaeni. (2010). Hukum Poerikanan Nasional dan Internasional, Jakarta : Gramedia Pustaka Utama.

Mohammad Sodik, Didik, (2011), Hukum Laut Internasional Dan
Pengaturannya Di Indonesia,

Bandung : Refika Aditama.

Internet

Wikipedia, (2016), tersedia

pada

https://id.wikipedia.org/wiki/Kabupate

n_Natuna [akses 18 Maret 2017].

Bappeda Kepulauan Riau, (2016), Potensi

daerahdi sektor perikanan,

tersedia pada

http://bappeda.kepriprov.go.id/index.php/da ta-dan-

informasi/2013-02-04-08-49-43/91-potensidaerah/180-sektor-perikanan [Akses

18 Maret 2017]

Rmol, (2016), Susi: tidak benar itu

traditional fisging ground China,

tersedia pada

http://m.rmol.co/read/2016/03/21/240

299/Menteri- Susi:-Tidak-Benar-Itu-

$\underline{\text { Traditional-Fishing-Ground- China- }}$ -

[Akses 28 Maret 2017]

Nusantara News, (2016), Pakar: tidak

ada traditional fishing ground

China, tersedia pada

http://nusantaranews.co/pakar-di-

dalam-zee-tidak- ada-traditional-

fishing-ground-china, [Akses 21

Maret 2017] 